\title{
Comparison of the Sensitivity of Spores and Amoebae of Dictyostelium discoideum to $\boldsymbol{\gamma}$-Rays and Ultraviolet Light
}

\author{
By N. E. GILLIES, N. HARI-RATNAJOTHI AND C. N. ONG* \\ Department of Biology as Applied to Medicine, The Middlesex Hospital Medical School, \\ London $W_{\mathrm{I}} P$ 6DB
}

(Received 28 May 1975; revised 2 September 1975)

INTRODUCTION

During development of the cellular slime mould Dictyostelium discoideum many biochemical changes take place (for review see Garrod \& Ashworth, 1973). To obtain information on events occurring during the germination of spores and development of the amoebae, we studied the sensitivity of the cells to ionizing and u.v. radiations as they pass through these stages.

\section{METHODS}

Slime mould. Dictyostelium discoideum strain NC4, kindly supplied by Dr P. Farnsworth, was used throughout. The amoebae of this strain require bacteria as a source of nutrients for growth and division.

Bacteria. The strains with which $D$. discoideum were grown were Escherichia coli $\mathrm{B} / \mathrm{r}$ $E$. coli $\mathrm{B}_{\mathrm{s}-2}$ and $E$. coli $\mathrm{DBI}$. These strains were maintained in our laboratory collection on nutrient agar slopes at $4{ }^{\circ} \mathrm{C}$.

Stock cultures of slime mould. Spores were incubated at $22{ }^{\circ} \mathrm{C}$ on plates of slime-mould nutrient agar (Sussman, 1966) which had been seeded with bacteria of the appropriate strain. The spores germinated, and the amoebae which emerged continued to divide until the bacterial food supply had been used up. The amoebae then aggregated and formed fruiting bodies containing spores. The plates were sealed and stored at $4{ }^{\circ} \mathrm{C}$ until required. Fresh supplies of slime mould cells were grown from stock spore cultures for each experiment.

Spore cultures. A suspension of spores in $67 \mathrm{mM}$-phosphate buffer, $\mathrm{pH} 7 \cdot 2$, was prepared by gently scraping spores from fruiting bodies with a sterile wire loop, and placing them in a few millilitres of the buffer. The concentration of spores was estimated from a count made on a haemocytometer slide and the density adjusted to $10^{6}$ spores $/ \mathrm{ml}$ for irradiation.

Amoebae cultures. These were prepared by germinating and growing spores for the required time on plates of slime-mould nutrient agar, seeded with the appropriate bacterial strain, at $22{ }^{\circ} \mathrm{C}$. Then the amoebae and remaining bacteria were washed off the plates with 67 mM-phosphate buffer, $\mathrm{pH} 7 \cdot 2$, containing $0.01 \mathrm{M}$-EDTA, and transferred into a plastic universal bottle. The bacteria were removed in the supernatant after centrifugation at $200 \mathrm{~g}$ for Io min. The amoebae were resuspended in $67 \mathrm{~mm}$-phosphate plus 0.01 M-EDTA, counted, and adjusted to $10^{6}$ amoebae/ml for irradiation.

Conditions for irradiation. The sources of $\gamma$-rays and u.v. light $(254 \mathrm{~nm})$ and the methods used for irradiation were as described for bacteria by Forage \& Gillies (1964) and Marshall, Gillies \& Panchapagesan (1973). Exposure to $\gamma$-rays was in the presence of oxygen-free nitrogen ('White Spot'; British Oxygen Co.). The dose rate of $\gamma$-rays was about $2 \mathrm{krad} / \mathrm{min}$ and that of u.v. irradiation was $15.5 \mathrm{~J} / \mathrm{m}^{2} / \mathrm{min}$.

* Present address: Department of Occupational Health, University of Manchester. 


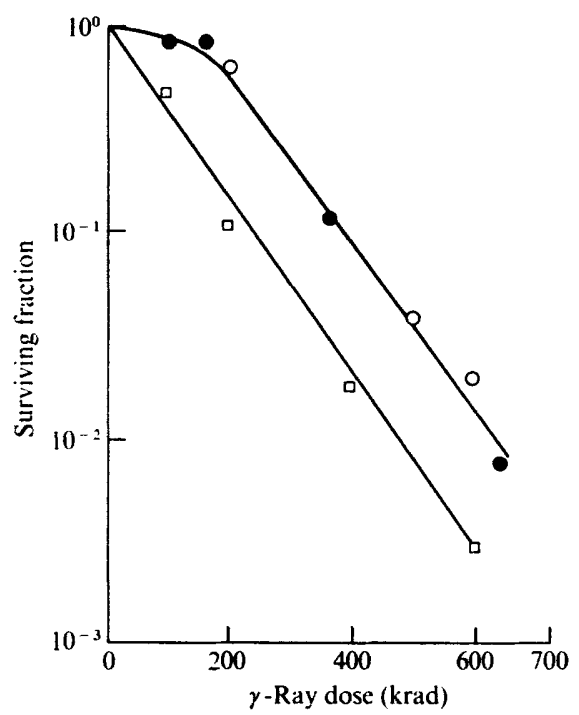

Fig. I. Survival of spores of $D$. discoideum after irradiation with $\gamma$-rays under anoxia. Cultures were grown before and after irradiation with $E$. coli $\mathrm{B}_{\mathrm{B}-2}(O), E$. coli $\mathrm{B} / \mathrm{r}(\Theta)$ or $E$. coli $\mathrm{DBI} \mathrm{I}(\square)$.

Scoring of viability. Bacteria of the same strain as that with which the slime mould had been grown were incubated to stationary phase in Oxoid nutrient broth. A portion $(0.3 \mathrm{ml})$ of this culture was spread on each plate of nutrient scoring medium (Sussman, 1966) and left to dry there, forming a lawn. Then slime mould cell suspensions were diluted with phosphate buffer so that 0.1 to $0.2 \mathrm{ml}$ contained approximately Ioo viable cells. This was dispensed and spread on each plate. The plates were incubated at $22^{\circ} \mathrm{C}$ for 72 to $96 \mathrm{~h}$. During this time the slime mould cells ingested bacteria from the underlying lawn and divided, giving rise to plaques which were easily identified and counted. It was assumed that each plaque originated from a single viable slime mould cell.

\section{RESULTS}

\section{Viability of cultures}

The proportion of unirradiated spores and amoebae able to originate plaques was always between 45 and $55 \%$. However, there is no reason to believe that the 'plating efficiency' of $50 \%$ was caused by selection of a sub-population of cells and it is assumed that the results below represent the characteristics of the cell population as a whole.

The effect of cell stage on the sensitivity of slime mould cells to irradiation

$\gamma$-Rays. Cells, at a given stage, were irradiated in the presence of nitrogen. Examples of the types of survival curves obtained for spores are illustrated in Fig. I. Survival was dependent on the strain of bacteria with which the cells were grown. The sensitivity of the cells to $\gamma$-rays increased with increasing age of the amoebae after the start of germination (Fig. 2a). It is difficult to draw exact comparisons of the relative sensitivities of the slime mould cells during development, because of differences in the shapes of the survival curves. However, approximate comparisons can be made by plotting the doses of $\gamma$-rays required to reduce survival to $\mathrm{I} \%$ of that of the unirradiated cells, against the time after the beginning of germination of the spores before the cells were exposed to $\gamma$-rays. Results for $\gamma$-irradiated cells exposed under anoxia and grown with $E$. coli $\mathrm{B}_{\mathrm{s}-2}$ are summarized in Fig. $2(b)$. 

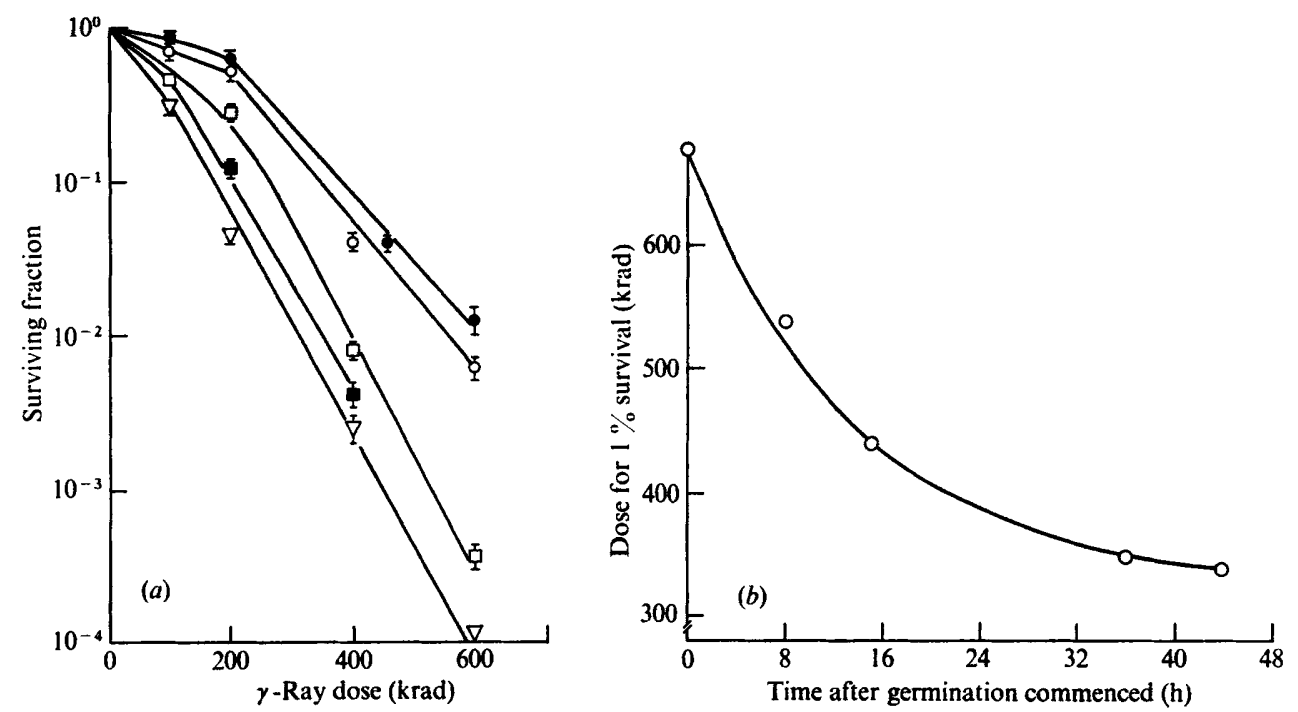

Fig. 2. Survival of $D$. discoideum after exposure to $\gamma$-rays under anoxia. Cultures were grown before and after irradiation with $E$. coli $\mathrm{B}_{\mathbf{8}-2}$. (a) Cells were irradiated as spores $(O)$, or were irradiated as amoebae at $8 \mathrm{~h}(0), 15 \mathrm{~h}(\square), 36 \mathrm{~h}(\square)$ and $44 \mathrm{~h}(\nabla)$ after the beginning of germination. (b) Survival ( $1 \%$ ) as a function of the time of irradiation after the beginning of germination. The time of irradiation of spores is represented by zero time.
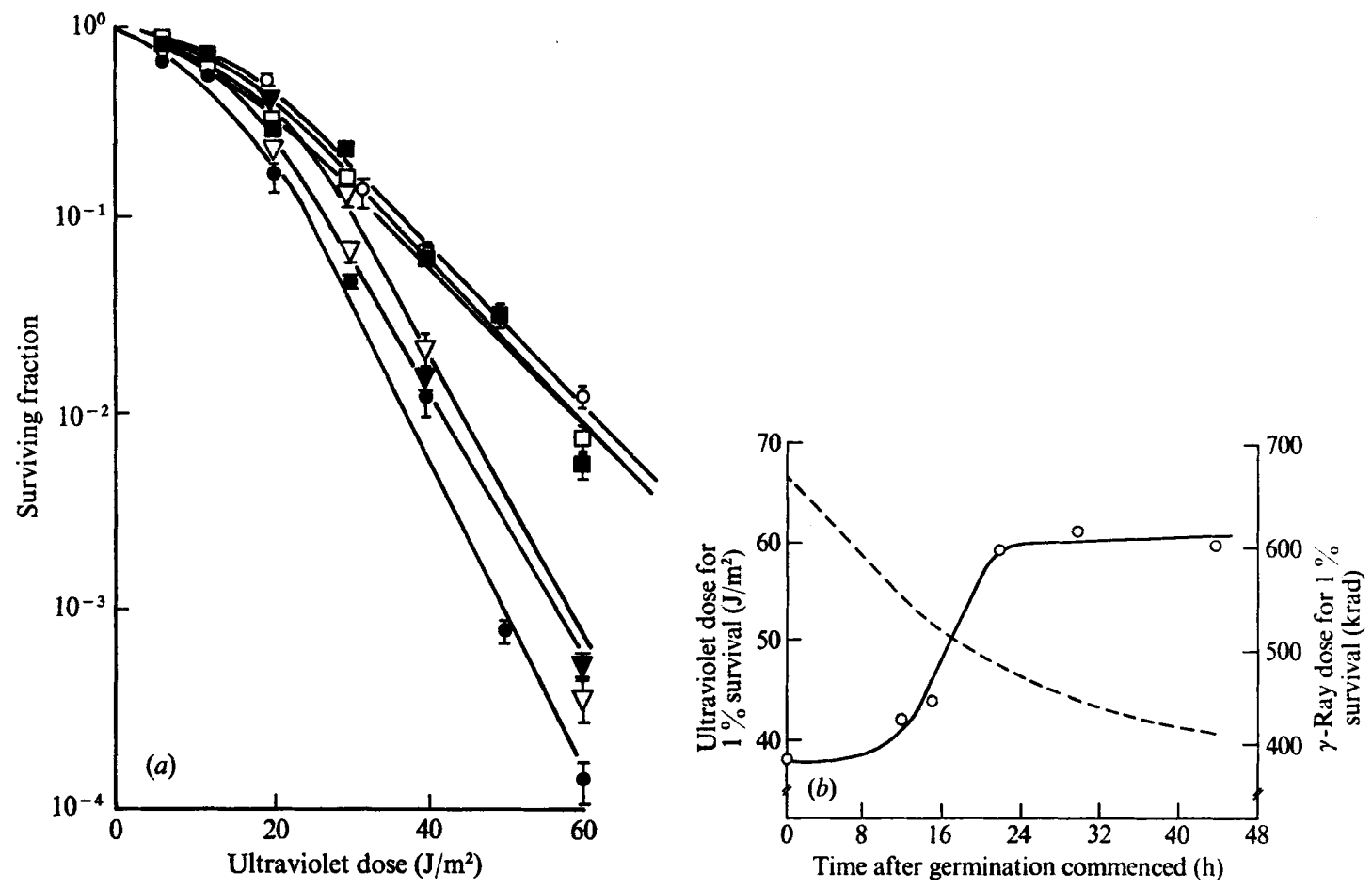

Fig. 3. Survival of $\boldsymbol{D}$. discoideum after exposure to u.v. irradiatior. Cultures were grown before and after irradiation with $E$. coli $\mathrm{B} / \mathrm{r}$. (a) Cells were irradiated as spores $(O)$, or were irradiated as amoebae at $12 \mathrm{~h}(\triangle)$, i $5 \mathrm{~h}(\Delta), 22 \mathrm{~h}(\square), 30 \mathrm{~h}(\square)$ and $44 \mathrm{~h}(O)$ after the beginning of germination. (b) Survival ( $1 \%$ ) as a function of the time of irradiation after the beginning of germination. For comparison, survival after exposure to $\gamma$-rays is represented by the dashed line. 
Ultraviolet irradiation. The survival of cells exposed to u.v. irradiation was independent of the bacterial strain with which they were grown. The u.v.-sensitivities of cells grown with $E$. coli $\mathrm{B} / \mathrm{r}$ for different times are shown in Fig. 3(a). Contrary to their response to $\gamma$-rays, the cells became progressively more resistant to u.v. irradiation with time after the start of germination. The results for cells grown with $E$. coli $\mathrm{B} / \mathrm{r}$ are summarized in Fig. $3(b)$. During the first $8 \mathrm{~h}$ after the commencement of germination the u.v.-sensitivity did not alter, but between 10 and $22 \mathrm{~h}$ it decreased sharply and afterwards remained at that level at least until aggregation of the amoebae began.

\section{DISCUSSION}

The sensitivity of $D$. discoideum to $\gamma$-rays increased during germination of the spores and division of the amoebae, while at the same time the cells became more resistant to u.v. irradiation. This is an unusual finding. Studies on other types of cells, particularly bacteria, have shown that cells which are relatively resistant to inactivation by ionizing radiations are usually resistant to u.v. irradiation, and vice versa (e.g. Howard-Flanders \& Boyce, 1966; Paterson, Boyle \& Setlow, 197I). This correlation is readily explained by the finding that several of the enzymic steps involved in the repair of damage operate against lesions induced by either type of radiation.

Repair of radiation-induced lesions in $D$. discoideum certainly does occur. In $\gamma$-rayresistant strains, repair of single strand breaks in DNA appears to be correlated with enhanced survival (Khoury \& Deering, 1973). No work has been published so far on the production and fate of u.v.-induced lesions in $D$. discoideum. However, Deering \& Jensen (1975) detected an endonuclease in homogenates of amoebae of $D$. discoideum NC4 which was active in producing single strand breaks in u.v.-irradiated $\phi X-174$ RFI DNA. This suggests that the cells may possess the ability to cope with u.v. damage. If the present results reflect a capacity to repair radiation-induced damage, then it would appear that, to some extent, such mechanisms for dealing with $\gamma$-ray- and with u.v.-induced lesions in $D$. discoideum operate independently of each other during germination and division of the cells.

We suggest that our results arose from differences in the ability of the cells to repair radiation damage in the period after exposure to radiation. To test this, we are examining the fate of biochemical lesions such as strand breaks and pyrimidine dimers under the conditions during which the survival of the cells was measured.

We are grateful to Mrs B. Hubbard and Mr I. Qureshi for their contributions to the work.

\section{REFERENCES}

DeEring, R. A. \& JeNSEN, D. S. (1975). Endonuclease from Dictyostelium discoideum that attacks ultraviolet-irradiated deoxyribonucleic acid. Journal of Bacteriology 121, 1211-1213.

ForAGE, A. J. \& Gillies, N. E. (1964). Restoration of Escherichia coli strain B after $\gamma$-irradiation. Journal of General Microbiology 37, 33-39.

Garrod, D. \& AshwORTh, J. M. (1973). Development of the cellular slime mould Dictyostelium discoideum. In Microbial differentiation, pp. 407-435. Edited by J. M. Ashworth and J. E. Smith. London: Cambridge University Press.

Howard-Flanders, P. \& Boyce, R. P. (I966). DNA repair and genetic recombination: studies on mutants of Escherichia coli defective in these processes. Radiation Research s 6, I56-184.

Khoury, A. T. \& DeEring, R. A. (1973). Sedimentation of DNA of Dictyostelium discoideum lysed on alkaline sucrose gradients: role of single strand breaks in gamma ray lethality of sensitive and resistant strains. Journal of Molecular Biology 79, 267-284. 
Marshall, N. J., Gillies, N. E. \& Panchapagesan, G. (I973). Rescue by chloramphenicol and rifampicin of UV-irradiated lon, exrA and recA mutants of Escherichia coli KI2. Mutation Research $19,145-152$.

PAterson, M. C., Boyle, J. M. \& SeTLOw, R. B. (197I). Ultraviolet- and X-ray induced responses of a deoxyribonucleic nucleic polymerase-deficient mutant of Escherichia coli. Journal of Bacteriology ro7, 6I-67.

Sussman, M. (1966). Biochemical and genetic methods in the study of cellular slime mold development. In Methods in Cell Physiology, vol. 2. pp. 397-410. Edited by D. M. Prescott. New York and London: Academic Press. 